\title{
Are young adults car-loving urbanites? Comparing young and older adults' residential location choice, travel behavior and attitudes
}

\author{
Jonas De Vos ${ }^{a,}{ }^{*}$, Farzad Alemi ${ }^{b}$ \\ Paper published in Transportation Research Part A: De Vos, J., Alemi, F., 2020. Are young adults car- \\ loving urbanites? Comparing young and older adults' residential location choice, travel behavior and \\ attitudes. Transportation Research Part A 132, 986-998.
}

\begin{abstract}
Previous studies mostly indicate that young adults travel less by car compared to their older counterparts, partly due to postponing driving license holding and car ownership. Furthermore, these young adults might also prefer living in urban, low-traffic neighborhoods, further reducing car use. In this study we analyze the residential location choice, travel behavior and travel attitudes of young versus older adults (respectively born after 1984 and before 1985), using 1,376 recently relocated residents from the city of Ghent (Belgium). Results indicate that travel mode frequency does not considerably differ between young and older adults, although young adults - compared to older adults - live more often in urban-type neighborhoods. This might be partly explained by young adults' relatively positive attitudes towards car use and negative attitudes towards walking and low-traffic investments. These attitudes consequently seem to counterbalance the effects of the residential neighborhood on travel mode frequency. The fact that respondents' travel attitudes are often not in line with their chosen residential neighborhood suggests limited self-selection effects. Results from this study partly contradict earlier findings on young adults' travel behavior and indicate that further research is needed on the links between travel behavior, attitudes and residential location choice of different age groups.
\end{abstract}

Keywords: Young adults; Travel behavior; Residential location choice; Attitudes

\section{Introduction}

Young adults, often referred to as "Millennials", which generally include those individuals born from the early 1980 s to the late 1990s, are mostly reported to have different travel behavior compared to their older cohorts. Among the observed trends, millennials obtain their driver's license at later ages (Delbosc \& Currie, 2013; Habib, 2018; Thigpen \& Handy, 2018), own fewer cars (or often live in a zerovehicle household) (Clark et al., 2016a), drive less, travel more active or by public transport (Blumenberg et al. 2012; Chatterjee et al., 2018; Frändberg \& Vilhelmson, 2011; Garikapati et al. 2016; Kuhnimhof et al., 2012a, 2012b; Lee et al. 2018), and potentially use emerging transportation services such as ridehailing services, carsharing and bikesharing (Alemi et al., 2018; Millard-Ball et al., 2005; Wang et al., 2018). Researchers have pointed out two major factors that lead to such differences in young adults' travel behavior. The first reason is lifestyle-related changes and the lag in major life course events. This includes changes in employment rates, delays in the start of the independent living from parents, marriage and childbearing. One of the major contributors to these changes is economic 
hardship that prevents current young adults from moving onto the next stage in their life and start their own household (Blumenberg et al., 2016; Delbosc \& Currie, 2013; Klein \& Smart, 2017; McDonald, 2015). This can also partially be attributed to the growth in a demand for higher educated labor (Millsap, 2018). As a result, millennials spend longer time in colleges and graduate schools, eventually resulting in the delay of getting married and having children.

The second underlying reason to such different behavior can be the shift in attitudes and adoption of information and communication technologies (ICT). Millennials are sometimes described as "digital native" due to their greater familiarity and comfort with the use of ICT compared to the members of previous generations, i.e., "digital immigrant" generations (Prensky, 2009). Current young adults are also reported to have more pragmatic attitudes towards vehicle ownership and use, and are more conscious of environmental and climate change issues compared to their older cohorts (Clark et al., 2016b; Line et al., 2010). Similarly, this segment of the population has higher preferences to live in urban areas closer to public transportation stations and frequently tends to work remotely and shop online instead of physical trips to work/school or shop (Delbosc \& Currie, 2014; Hopkins, 2016; Lee et al., 2019; Puhe \& Schippl, 2014).

It is important to note that not all millennials are the stereotyped millennials: similar to the members of other generations, the behavior of millennials is not homogenous. For example, Garikapati et al. (2016) - analyzing differences in the activity-time use patterns of younger and older millennials indicates that younger millennials (born 1988 - 1994) spend significantly more time on in-home activities than older millennials (born 1979 - 1985). In another study, Alemi et al. (2018) showed that adoption of ridehailing services (services such as Uber and Lyft in the US market) is higher among independent millennials (those who have already established their household), compared to dependent millennials (those who live with their family of origin). Another contributing factor to the heterogeneity in the behavior of current young adults and the differences in their travel behavior is the local context in which millennials live and work/study. For instance, Delbosc et al. (2019) exploring travel behavior of millennials in six urban areas of the UK, USA and Australia - indicate that the existing transport systems in these areas play an important role in explaining millennials' travel. Furthermore, it can also be expected that the geographical and cultural context affects young adults' travel patterns.

Studies also found that current young adults tend to concentrate in central areas of cities and urban neighborhoods, close to major activities while saving some money by adopting a car-less/carindependent lifestyle (Lee, 2018; Lee et al., 2019; Moos, 2016). The fact that young adults often reside in urban neighborhoods can also be regarded as an important reason why young adults' travel behavior differs from that of older adults. Since urban areas discourage car use, young adults living in these areas will be inclined to frequently travel by car alternatives (Melia et al., 2018; Oakil et al., 2016). This choice to live in urban areas might be caused by millennial's higher cost sensitivity and urban lifestyle orientations, but also by positive attitudes towards active travel and public transport (McDonald, 2015; Puhe \& Schippl, 2014). Since compact, mixed-use neighborhoods stimulate the use of these modes, young adults might prefer an urban neighborhood to live in. Lee et al. (2019) - conducting a latent class choice model to disentangle millennials' residential preferences - indicate that although most millennials prefer an urban-style neighborhood, their preferences are not homogeneous. The authors identified three latent classes of individuals, comprising of (1) younger, pro-urban class $(53 \%$ of the 
sample), the stereotypical millennials as labeled in popular media, who are more likely to reside in urban areas; (2) the affluent, highly-educated class (32\% of the sample), who are more likely to follow the paths pursued by the older cohorts by valuing homeownership or good school districts; and (3) the middle-class homeowner class ( $15 \%$ of the sample) who are already one step ahead of their cohorts and has already accepted the traditional family-oriented suburban lifestyles.

However, to what extent will these differences in travel behavior persist as young adults age, and move to next stage of their life? For example, will improvements in economic conditions and changes in young adults' stage of life affect their residential location choices and travel choices? Many studies report that millennials' travel behavior and residential location choices will be very similar to those of preceding generations, and they just put off the move to suburbs and use of personal vehicles for a few years (e.g., Busch-Geertsema \& Lanzendorf, 2017; Clark et al., 2016b; Delbosc, 2017; De Paepe et al., 2018; Newbold \& Scott, 2017). However, this shift of young adults to car use might be partly imposed, as they might not always have a free choice of where to live. In a qualitative study, Delbosc and Nakanishi (2017) analyzed the interactions between life course and mobility of millennials in three Australian cities and found that - when moving to another stage in life - millennials face difficulties in finding suitable housing near transit, which can lead to the use of less sustainable transportation options when being forced to move to more suburban neighborhoods.

Although numerous studies have analyzed young adults' travel behavior (often comparing it with travel behavior of older generations), the role of the residential location - which can significantly impact travel behavior (e.g., Ewing \& Cervero, 2010) - and the effects of travel attitudes on the residential location choice remain, in the context of young adults' travel behavior, underexplored. In this paper we will analyze travel behavior of young versus older adults (respectively born after 1984 and before 1985) within the city of Ghent (Belgium). For both groups, we will analyze the potential direct effects of the residential neighborhood type - and the direct and indirect effects (through the residential location choice) of travel attitudes - on travel behavior. Up till now, studies focusing on young adults' travel behavior have not thoroughly examined the effect of both the residential location and travel attitudes on travel behavior differences between young and older adults. As a result, this study can provide valuable insights into the links between the residential location, travel attitudes and travel behavior of young adults, helping researchers and policy makers to better disentangle the reasons behind young adults' behaviors and understand what these mean for possible changes to their travel in the near future. This paper is organized as follows. Section 2 describes the neighborhood selection, sample recruitment, data representativeness, and key variables used in this study. Section 3 provides the main results and indicates how the residential location choice, travel mode frequencies and travel attitudes differ according to young and older adults. In Section 4 we discuss the main results and provide a conclusion. The results of this study indicate that younger adults have - compared to older adults - similar travel patterns but more positive attitudes towards driving, while residing more frequently in urban neighborhoods. These results partly contradict previous studies, indicating that more research is desired on the relationships between the residential location choice, travel behavior and attitudes for various age cohorts. 


\section{Data}

For this study we use data from a 2017 online survey on travel behavior of recently relocated residents. Two internally homogeneous sets of urban and suburban neighborhoods within the city of Ghent (Belgium; 258,000 inhabitants) were selected. In February 2017, 9,979 survey invitations were distributed among all the households within the selected neighborhoods that relocated in the last two years (i.e., between January 2015 and December 2016). ${ }^{1}$ Since we assumed that residential mobility would be higher in urban neighborhoods than in suburban neighborhoods, we selected a relatively large number of suburban neighborhoods (with approximately 61,600 inhabitants) and a relatively smaller number of urban neighborhoods (with approximately 39,700 inhabitants). Despite this effort to reach an equal amount of recently relocated urban and suburban residents, considerably more households moved to the selected urban neighborhoods compared to the suburban neighborhoods (i.e., 6,391 versus 3,588 households), indicating that residential mobility is 2.77 times higher in the selected urban neighborhoods than in the selected suburban neighborhoods. In the end, 1,650 (adult) respondents completed the survey, resulting in a response rate of $16.5 \%$. For this study we have removed students, unemployed people, and retired respondents since we expect that their residential location choice and travel patterns might be different from those who work only (e.g., students have limited choices in where to live; retired/unemployed people do not perform commute trips). In the end, we use 1,376 respondents for this study. For more details on the neighborhood selection and sampling recruitment, see De Vos et al. $(2018,2019)$.

\subsection{Selected neighborhoods and residents}

The group of urban neighborhoods are located directly around the central business area and are all built before the Second World War. These neighborhoods are characterized by a relatively high average density $\left(8,000\right.$ inhabitants per $\left.\mathrm{km}^{2}\right)$, highly mixed land uses and can be regarded as low-traffic areas with good public transport services. In general, the street network is characterized by high intersection density, small building blocks, $\mathrm{X}$-intersections and limited dead-end streets. As a result, street connectivity is high, stimulating active travel. The suburban neighborhoods are located at the edge of the city of Ghent, around 3 to 6 kilometers from the city center. These neighborhoods are for most parts built after the Second World War. They have a considerably lower average density $(1,800$ inhabitants per $\mathrm{km}^{2}$ ), lower diversity, and limited public transport services. The street network is characterized by relatively low intersection density, large building blocks, and a high number of Tintersections and dead-end streets. The resulting low levels of connectivity stimulate car use and discourage active travel. Approximately 101,300 people (situation 2017) reside in the selected neighborhoods, accounting for $39.3 \%$ of all residents in the city of Ghent (http://gent.buurtmonitor.be).

Also in terms of residents' socio-demographics, considerable differences can be found between residents of urban and suburban neighborhoods. In comparison with urban neighborhoods, suburban neighborhoods are characterized by larger household sizes. Couples, often with children, tend to live in suburban neighborhoods, while more than half of the residents in urban areas are singles. Young adults (between the age of 20 and 39 ) are well represented in urban neighborhoods, while older adults

\footnotetext{
${ }^{1}$ Addresses of inhabitants relocating to the set of selected urban and suburban neighborhoods between January 2015 and December 2016 were obtained from the city of Ghent administration.
} 
$(40+)$ reside more often in suburban neighborhoods. The urban neighborhoods are - compared to suburban neighborhoods - characterized by lower median incomes, a higher unemployment rate, and a higher share of citizens from outside the EU-15 area (http://gent.buurtmonitor.be). Besides older people being underrepresented in our sample (See Section 2.2), other socio-demographics of our respondents (e.g., income, gender, employment status) are comparable to the total population of the selected neighborhoods (see De Vos et al., 2018). Since older adults are less likely to move (compared to young adults), they are not only underrepresented in our sample, but might also have travel patterns and attitudes developed in their previous residential neighborhood, where they might have lived for a long time. Hence, results gained from older adults should be treated with caution. Although we do not have a fully representative sample of the total population of selected neighborhoods, we do have a relatively large sample size, making it possible to estimate relationships with ample confidence. ${ }^{2}$ In this study we use cross-sectional data, making it impossible to measure changes in respondents' residential location choice, travel patterns and attitudes over time. As a result, we cannot know whether young adults will change their behavior and attitudes in the future so they will become similar to older adults' current attitudes and behavior. Although this is a significant drawback, the used data provides us with detailed information on young and older adults' residential location choice, travel behavior and attitudes at a certain point in time.

\subsection{Young versus older adults}

Respondents in our sample are relatively young (i.e., 32.9 year on average), considerably younger than the total (adult) population of the selected neighborhoods (see De Vos et al., 2018). This is not very surprising, since young adults are more likely to relocate due to important life events which mostly take place in people's twenties and thirties (e.g., leaving the parental home, going to university, entry into the labor market, formation of a household with partner and having children). This young group of recently relocated respondents can provide important information on young adult's residential location choice and makes it possible to thoroughly examine the links between young adults' residential location and travel behavior. Respondents are subdivided into two groups based on their age. Respondents born in 1985 or later (31 years old or younger at the time of filling out the survey) are labelled as young adults, while respondents born before 1985 (32 years old or older when filling out the survey) are labeled as older adults. We acknowledge that this subdivision is rather arbitrary. Since other travel behavior studies focusing on young adults do not use a standardized threshold, we have chosen to create two groups which both contain a substantial amount of the respondents. ${ }^{3}$ Furthermore, we see that residential mobility considerably decreases between the age of 28 and 34 . The group of respondents aged 31 is the last group over 50 individuals; older age groups become

\footnotetext{
${ }^{2}$ Although our sample might not be representative for the population of the selected neighborhoods, it is probably more representative for the group of people relocating to these neighborhoods (since all recently relocated residents in the selected neighborhoods were invited to participate). However, since we do not have information on the socio-demographics of all movers, we cannot claim to have a representative sample of relocated residents.

${ }^{3}$ A considerable number of travel studies assimilates young adults with Millennials or generation $Y$ (i.e., people born in the 1980s and 1990s). However, since we use recent data (i.e., from 2017), people born in the beginning of the eighties are already around 35 years old in our sample and might therefore not be regarded as young adults anymore. It can be expected that future studies on young adults' travel behavior will focus more and more on generation $\mathrm{Z}$ (people born at the end of the 1990s and later) instead of generation $\mathrm{Y}$.
} 
smaller and smaller, indicating lower residential mobility. Having children might be an important reason for households to relocate. The percentage of households having one or more children considerably starts increasing at respondents' late twenties and reaches its highest level at the age of 40 to 45 . The group of respondents aged 31 is the last age group with less than $30 \%$ of households with children. Older age groups contain a higher percentage of households with children (until it reaches a peak around $70 \%$ for respondents between 41 and 45 years old).

Table 1 indicates that respondents between the age of 24 and 27 are best represented. Group sizes become smaller when moving to older age groups, indicating that residential mobility is largest for people in their late twenties and decreases thereafter. Table 1 also shows that young adults are highly educated, mostly full-time employed, and mostly live in households without children. Older adults, on the other hand, are somewhat less educated, less full-time employed, have a somewhat higher household income and household car possession and often live in a household with children.

Table 1. Socio-demographics of young and older adults

\begin{tabular}{|c|c|c|c|}
\hline & & $\begin{array}{c}\text { Young adults } \\
\text { (Aged } 18-31 \text { ) }\end{array}$ & $\begin{array}{c}\text { Older adults } \\
\text { (Aged } 32-65)\end{array}$ \\
\hline Personal & characteristics & $\%$ & $\%$ \\
\hline \multicolumn{4}{|c|}{ Age distribution (young adults - older adults) } \\
\hline $18-23$ & $32-39$ & 8.0 & 48.4 \\
\hline $24-27$ & $40-49$ & 59.5 & 26.8 \\
\hline $28-31$ & $50-65$ & 32.5 & 24.8 \\
\hline \multicolumn{4}{|l|}{ Gender } \\
\hline Female & & 49.4 & 44.2 \\
\hline Male & & 50.6 & 55.8 \\
\hline \multicolumn{4}{|c|}{ Education } \\
\hline Low ed & ucation (primary or secondary education) & 15.3 & 24.1 \\
\hline High ec & ucation (University (college) degree) & 84.7 & 75.9 \\
\hline \multicolumn{4}{|c|}{ Job status } \\
\hline Full tim & e employed & 90.4 & 82.2 \\
\hline Part tir & e employed & 9.6 & 17.8 \\
\hline \multicolumn{4}{|c|}{ Household characteristics } \\
\hline \multicolumn{4}{|c|}{ Household composition } \\
\hline Single & & 29.2 & 26.6 \\
\hline Single & arent & 0.5 & 14.0 \\
\hline Couple & without children & 48.3 & 21.2 \\
\hline Couple & with children & 5.2 & 33.3 \\
\hline Other & e.g., living with parents, with friends) & 16.8 & 4.9 \\
\hline \multicolumn{4}{|c|}{ Household net income/month } \\
\hline Low in & ome (<2000 euro) & 40.8 & 25.7 \\
\hline Mediu & income (2000 - 3,499 euro) & 34.5 & 35.6 \\
\hline High in & ome (3500+ euro) & 24.7 & 38.7 \\
\hline \multicolumn{4}{|c|}{ Household car possession } \\
\hline 0 & & 26.8 & 16.5 \\
\hline 1 & & 54.3 & 57.1 \\
\hline$>1$ & & 18.9 & 26.4 \\
\hline $\mathrm{N}$ & & 824 & 552 \\
\hline$\%$ & & 59.9 & 40.1 \\
\hline
\end{tabular}




\subsection{Travel behavior}

In the survey we asked respondents information regarding their mode frequency. On a scale from 1 to 5 (representing respectively never, rarely, sometimes, often and always), respondents were asked to indicate how often they use various travel modes (i.e., car; bus/tram; train; cycling; walking) for both commute trips and leisure trips. In the remainder of the paper, we labeled respondents with frequency level 4 (often) or 5 (always) as frequent users of the reported mode. For commute trips, we also asked the average distance and duration of a typical trip to work.

\subsection{Travel attitudes}

In order to get an indication of respondents' attitudes towards travel, and travel modes in particular, we asked them to what extent they agree on fourteen attitudinal statement on a scale from 1 (totally disagree) to 5 (totally agree). Average scores on these statements - shown in Table 2 - indicate that respondents especially like walking and cycling, prefer activities accessible by active travel, and would like to see more investments in public transport and cycling infrastructure. Based on a factor analysis (principal axis factoring; promax rotation), four factors - explaining $65.3 \%$ of the total variance - can be identified: Pro car, Pro low-traffic investments, Pro walking, and Pro cycling (Table 2).

Table 2. Factors for travel attitudes

\begin{tabular}{llc}
\hline Factor (explained variance) & Statement (average score on statement) & Loading \\
\hline Pro car (35.0\%) & I need a car to feel free (3.07) & 0.79 \\
& I like traveling by car (3.45) & 0.72 \\
& City centers should be/remain well accessible by car (2.99) & 0.61 \\
& Car use should be taxed more heavily (2.65) & -0.49 \\
& I like using public transport (2.82) & -0.41 \\
& Cities should be low-traffic areas (3.55) & -0.34 \\
\hline Pro low-traffic investments & Cities should be low-traffic areas (3.55) & 0.62 \\
(12.6\%) & Streets should be walk friendly (4.21) & 0.62 \\
& More investment in cycling infrastructure is needed (4.31) & 0.55 \\
& More investment in public transport is needed (4.05) & 0.50 \\
& Car use should be taxed more heavily (2.65) & 0.37 \\
\hline Pro walking (9.2\%) & Destinations should be well accessible on foot (4.26) & 0.77 \\
& I like to walk (4.04) & 0.59 \\
& I like using public transport (2.82) & 0.30 \\
\hline Pro cycling (8.4\%) & I like cycling (4.16) & 0.74 \\
& Destinations should be well accessible by bike (4.51) & 0.50 \\
\hline
\end{tabular}

Note: In order to improve readability, only statements with a factor loading of at least 0.30 in magnitude are shown. Since the statement 'Public transport is unreliable' did not load clearly on one of the factors, we have removed this statement from the factor analysis.

\section{Results}

\subsection{Residential location choice, travel behavior and travel attitudes of young versus older adults}

Table 3 shows that the residential location choice of young adults significantly differs from older adults' residential location choice. Most young adults (78.0\%) moved to an urban neighborhood, while only a small share $(22.0 \%)$ moved to one of the selected suburban neighborhoods. The group of older adults living in urban areas (51.4\%) is about the same size as the group of older adults living in suburban neighborhoods (48.6\%). Differences in travel behavior between young and older adults are limited. Young adults cycle and use the train somewhat more compared to older adults, while car use, bus/tram 
use and walking is similar. Overall, respondents most frequently cycle, followed by car use and walking. Bus/tram use, and train use are lowest (although the train is used rather frequently for commute trips). The average distance and duration of commute trips is similar between young and older adults. Finally, Table 3 shows that older adults have a significantly more positive attitude towards low-traffic investments, while young adults have a somewhat (albeit non-significant) more positive stance towards car use and cycling and a more negative stance towards walking.

Table 3. Residential location choice, travel behavior and travel attitudes of young versus older adults

\begin{tabular}{|c|c|c|c|}
\hline & $\begin{array}{c}\text { Young adults } \\
N=824\end{array}$ & $\begin{array}{c}\text { Older adults } \\
N=552\end{array}$ & P-value \\
\hline \multicolumn{4}{|l|}{ Residential location choice } \\
\hline Urban & $78.0 \%$ & $51.4 \%$ & 0.00 \\
\hline \multicolumn{4}{|l|}{ Travel behavior } \\
\hline Frequent car use (commute) & $38.1 \%$ & $40.8 \%$ & 0.32 \\
\hline Frequent car use (leisure) & $40.7 \%$ & $41.1 \%$ & 0.86 \\
\hline Frequent bus/tram use (commute) & $10.2 \%$ & $12.9 \%$ & 0.13 \\
\hline Frequent bus/tram use (leisure) & $10.6 \%$ & $11.4 \%$ & 0.62 \\
\hline Frequent train use (commute) & $22.0 \%$ & $16.8 \%$ & 0.02 \\
\hline Frequent train use (leisure) & $11.0 \%$ & $6.2 \%$ & 0.02 \\
\hline Frequent cycling (commute) & $49.4 \%$ & $42.6 \%$ & 0.01 \\
\hline Frequent cycling (leisure) & $58.5 \%$ & $50.7 \%$ & 0.00 \\
\hline Frequent walking (commute) & $25.0 \%$ & $25.0 \%$ & 1.00 \\
\hline Frequent walking (leisure) & $42.8 \%$ & $37.9 \%$ & 0.07 \\
\hline Distance of a typical one-way commute trip & $22.7 \mathrm{~km}$ & $21.2 \mathrm{~km}$ & 0.28 \\
\hline Duration of a typical one-way commute trip & $30.9 \mathrm{~min}$. & $29.6 \mathrm{~min}$. & 0.35 \\
\hline \multicolumn{4}{|l|}{ Travel attitudes } \\
\hline Pro car & 0.03 & -0.04 & 0.16 \\
\hline Pro low-traffic investments & -0.06 & 0.09 & 0.00 \\
\hline Pro walking & -0.03 & 0.04 & 0.18 \\
\hline Pro cycling & 0.03 & -0.04 & 0.18 \\
\hline
\end{tabular}

Note: P-values of the residential location choice and mode frequency are based on chi-square tests. P-values of commute distance, commute duration and attitudes are based on two-sample t-tests.

\subsection{Travel behavior and attitudes of four groups based on a $2 \times 2$ classification of age and residential location}

In order to see whether travel behavior and attitudes are most affected by respondents' age group or by their residential location, we subdivide respondents into four groups based on a $2 \times 2$ classification of age and residential location: young urban, older urban, young suburban, and older suburban. Doing so, we control for the fact that young people live considerably more in urban neighborhoods than in suburban neighborhoods. Table 4 shows how respondents in these four groups travel and what their stance towards travel is. Two-way ANOVAs were conducted to evaluate the impact of residential location, age group and the interaction of these two variables on travel behavior and travel attitudes. Results indicate that travel mode frequency is largely affected by respondents' place of residence. Urban respondents travel less frequently by car and walk, cycle and use public transport more frequently. The effect of age group on mode frequency is less clear. Older adults walk and use bus and tram (for commute trips) more frequently, while travel less frequently by car (for leisure trips) than young adults. Young adults cycle - compared to older adults - more frequently in urban areas while less frequently in suburban areas. Somewhat surprisingly, commute distance and duration are longer 
for urban than for suburban respondents. This can be partly explained by a relatively high share of urban residents using the train for commute trips (e.g., to larger cities such as Brussels and Antwerp).

Travel attitudes seem affected by both the age group and the built environment. Urban respondents have a more positive stance towards walking and cycling and a more negative stance towards car use compared to suburban respondents. Although urban respondents have significantly more positive attitudes towards low-traffic investments compared to suburban respondents, the effect of the age group seems stronger as older suburban respondents have a somewhat higher average factor score compared to young urban respondents. Except for cycling attitudes, the age group significantly affects travel attitudes, albeit less strong than the built environment (apart from attitudes towards low-traffic investments). Young adults are - compared to older adults - more positive towards car use, while more negative towards walking and low-traffic investments. Although the differences are non-significant, young adults have - compared to older adults - somewhat more positive attitudes towards cycling in urban areas, while slightly more negative attitudes towards cycling in suburban areas.

Table 4. Travel behavior and attitudes of four groups based on a $2 \times 2$ classification of age and residential location

\begin{tabular}{|c|c|c|c|c|c|}
\hline & $\begin{array}{c}\text { Young } \\
\text { urban } \\
\mathrm{N}=643\end{array}$ & $\begin{array}{c}\text { Older } \\
\text { urban } \\
\mathrm{N}=284\end{array}$ & $\begin{array}{c}\text { Young } \\
\text { suburban } \\
\mathrm{N}=181\end{array}$ & $\begin{array}{c}\text { Older } \\
\text { suburban } \\
N=268\end{array}$ & $\begin{array}{c}\text { Significant } \\
\text { effect }\end{array}$ \\
\hline \multicolumn{6}{|l|}{ Travel behavior } \\
\hline Frequent car use (commute) & $32.0 \%$ & $28.9 \%$ & $59.7 \%$ & $53.4 \%$ & $\mathrm{RL}$ \\
\hline Frequent car use (leisure) & $32.0 \%$ & $25.0 \%$ & $71.3 \%$ & $58.2 \%$ & Age, $\mathrm{RL}$ \\
\hline Frequent bus/tram use (commute) & $11.2 \%$ & $15.5 \%$ & $6.6 \%$ & $10.1 \%$ & Age, $\mathrm{RL}$ \\
\hline Frequent bus/tram use (leisure) & $11.7 \%$ & $13.0 \%$ & $6.6 \%$ & $9.7 \%$ & $\mathrm{RL}$ \\
\hline Frequent train use (commute) & $25.5 \%$ & $23.6 \%$ & $9.4 \%$ & $9.7 \%$ & $\mathrm{RL}$ \\
\hline Frequent train use (leisure) & $13.7 \%$ & $9.2 \%$ & $1.7 \%$ & $3.0 \%$ & $\mathrm{RL}$ \\
\hline Frequent cycling (commute) & $53.5 \%$ & $46.5 \%$ & $34.8 \%$ & $38.4 \%$ & $\mathrm{RL}, \mathrm{Age}{ }^{*} \mathrm{RL}$ \\
\hline Frequent cycling (leisure) & $65.0 \%$ & $60.2 \%$ & $35.4 \%$ & $40.7 \%$ & $\mathrm{RL}, \mathrm{Age} \mathrm{R}^{\mathrm{RL}}$ \\
\hline Frequent walking (commute) & $29.9 \%$ & $39.8 \%$ & $7.7 \%$ & $9.3 \%$ & Age, $R L$, Age*RL \\
\hline Frequent walking (leisure) & $52.3 \%$ & $58.1 \%$ & $9.4 \%$ & $16.4 \%$ & Age, $R L$ \\
\hline Distance of a typical commute trip & $23.3 \mathrm{~km}$ & $23.0 \mathrm{~km}$ & $20.5 \mathrm{~km}$ & $19.3 \mathrm{~km}$ & $\mathrm{RL}$ \\
\hline Duration of a typical commute trip & $31.7 \mathrm{~min}$. & $31.5 \mathrm{~min}$. & $27.8 \mathrm{~min}$. & $27.7 \mathrm{~min}$. & $\mathrm{RL}$ \\
\hline \multicolumn{6}{|l|}{ Travel attitudes } \\
\hline Pro car & -0.09 & -0.25 & 0.45 & 0.18 & Age, $\mathrm{RL}$ \\
\hline Pro low-traffic investments & -0.01 & 0.14 & -0.21 & 0.03 & Age, $\mathrm{RL}$ \\
\hline Pro walking & 0.05 & 0.20 & -0.31 & -0.13 & Age, $\mathrm{RL}$ \\
\hline Pro cycling & 0.09 & 0.01 & -0.21 & -0.09 & $\mathrm{RL}$ \\
\hline
\end{tabular}

Note: Significant effects at $\mathrm{p}<0.05$ are presented, based on two-way ANOVAs (RL = residential location; Age* $\mathrm{RL}$ represents interaction effects).

\subsection{Travel behavior of young and older adults based on a $2 \times 2$ classification of travel attitudes and residential location}

In order to see whether travel attitudes affect the residential location choice of both young and older adults, we have subdivided respondents based on their chosen residential neighborhood (urban versus 
suburban) and their attitudes towards car use. ${ }^{4}$ For the latter we grouped respondents with a positive score on the 'Pro car' factor (explaining $35.0 \%$ of the total variance) as individuals with a positive attitude towards car use, and respondents with a negative score on this factor as individuals with a negative attitude towards car use. In line with the residential self-selection hypothesis - indicating that people (try to) choose a residential neighborhood enabling a preferred way of traveling (e.g., Cao et al., 2009) - the former group will most likely have a preference for living in a suburban-style neighborhood, while the latter group will probably prefer living in urban environments. Table 5 shows that somewhat more than half of the young adults (52.8\%) prefers car use, while slightly more than half of the older adults (52.7\%) prefers car alternatives (difference in travel preference between young and older adults is significant at $p<0.05$; based on Chi-square test). When combining respondents' residential location and travel preferences, four groups can be created: Urban residents preferring car alternatives (urban consonants), urban residents preferring car use (urban dissonants), suburban residents preferring car use (suburban consonants), and suburban residents preferring car alternatives (suburban dissonants). Somewhat surprisingly, a large group of young urban adults $(46.8 \%$ (36.5\% / 78.0\%)) actually likes to drive and therefore might prefer suburban neighborhoods. For the three other groups (young suburban, older urban, and older suburban), the chosen neighborhood seems more in line with respondents' travel preferences. This might suggest that young adults are often forced to live in urban neighborhoods, possibly due to their high cost sensitivity. Since the costs of driving have increased considerably over the last decades (e.g., Klein \& Smart, 2017; Mcdonald, 2015), living in urban neighborhoods can save a considerable amount of money for the often financially weak young adults. Although city centers are rarely inexpensive places to live in, the lower travel costs (but also smaller housing units) might - especially for young adults - make them more affordable compared to suburban neighborhoods.

Table 5. Young and older adults' residential location choice and travel attitudes

\begin{tabular}{lcc}
\hline & $\begin{array}{c}\text { Young adults } \\
\mathrm{N}=824\end{array}$ & $\begin{array}{c}\text { Older adults } \\
\mathrm{N}=552\end{array}$ \\
\hline Residential location & & \\
Urban neighborhood & $78.0 \%$ & $51.4 \%$ \\
Suburban neighborhood & $22.0 \%$ & $48.6 \%$ \\
\hline Travel preference & & \\
Pro car alternatives & $47.2 \%$ & $52.7 \%$ \\
Pro car & $52.8 \%$ & $47.3 \%$ \\
\hline Residential location $x$ travel preference & & \\
Urban consonant & $41.5 \%$ & $31.5 \%$ \\
Urban dissonant & $36.5 \%$ & $19.9 \%$ \\
Suburban consonant & $16.3 \%$ & $27.4 \%$ \\
Suburban dissonant & $5.7 \%$ & $21.2 \%$ \\
\hline
\end{tabular}

Figure 1 shows young (top) and older (bottom) adults' mode frequency according to the four groups (based on a $2 \times 2$ classification of travel attitudes and residential location). Doing so makes it possible to see how mode frequency is affected by the residential location and attitudes, and whether this differs between young and older adults. Besides differences in mode frequency between young and

\footnotetext{
${ }^{4} \mathrm{~A}$ considerable number of studies has used a similar $2 \times 2$ classification based on travel attitudes and residential location in order to analyze the extent of dissonance between attitudes and residential location, and its effects on travel behavior (e.g., Cho \& Rodriguez, 2014; De Vos et al., 2012; Schwanen \& Mokhtarian, 2005).
} 
older adults (see Section 3.1), mode frequencies of the four groups are rather similar between young and older adults, suggesting that attitudes and the built environment have a similar effect on mode frequency. Car use is both affected by the residential location and attitudes. Urban residents travel less by car than suburban residents, while a positive attitude towards car also has a positive effect on driving. Since car use of suburban consonants is higher than car use of urban dissonants, this might suggest that the built environment has a stronger effect on car use than attitudes (although no robust conclusions can be made based on results presented in Figure 1). Walking and public transport use also seem affected by attitudes and especially the built environment: urban respondents walk and use public transport more than suburban residents, while positive car attitudes seem to negatively affect walking and public transport ridership. Finally, cycling seems more affected by attitudes than by the residential environment. Respondents with a negative attitude towards car use clearly have the highest frequency of cycling. For respondents liking to drive, cycling frequency is higher for urban respondents than for suburban respondents, suggesting that cycling is also partly affected by the built environment. 


\section{Young adults}

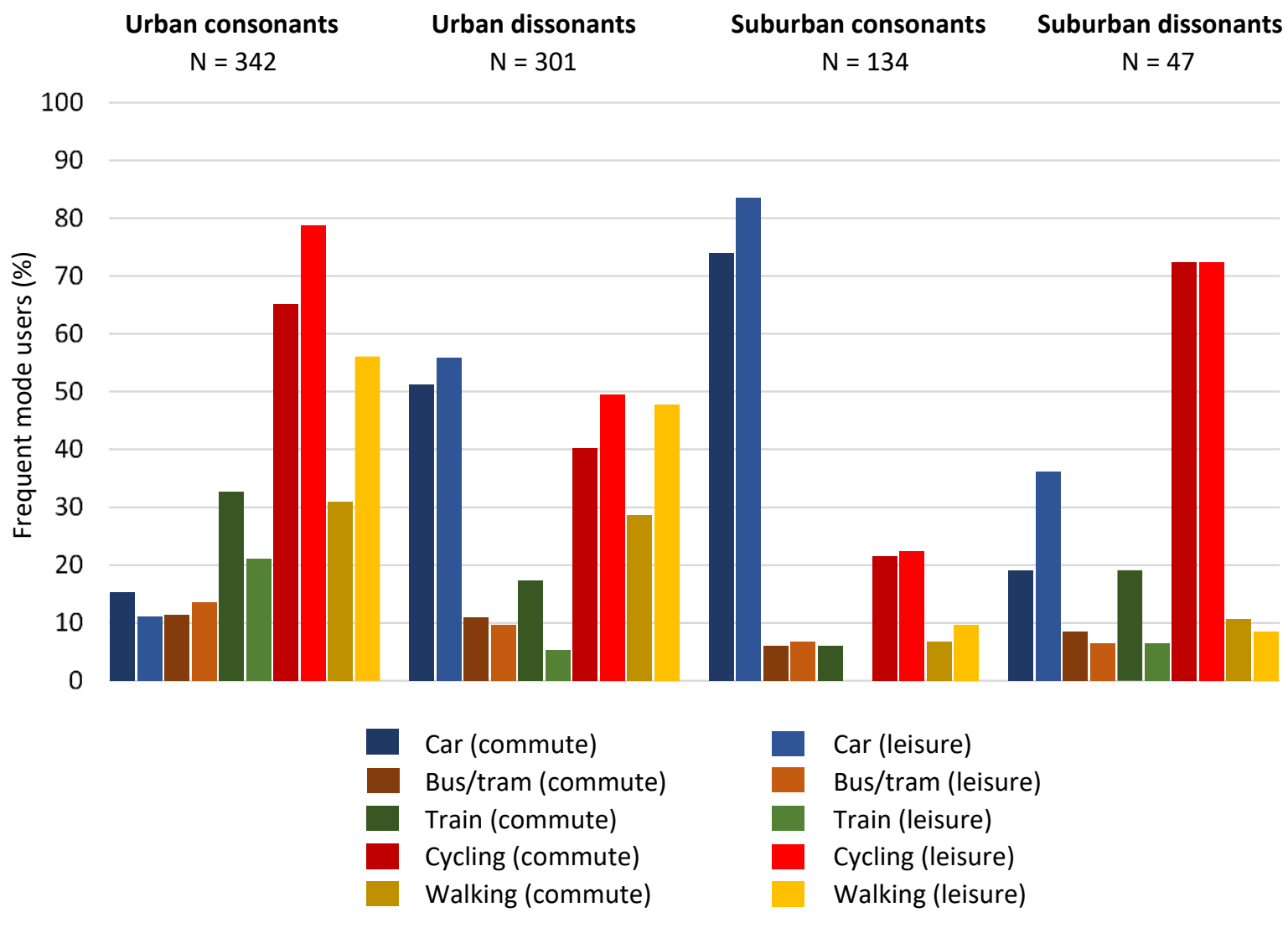

Older adults

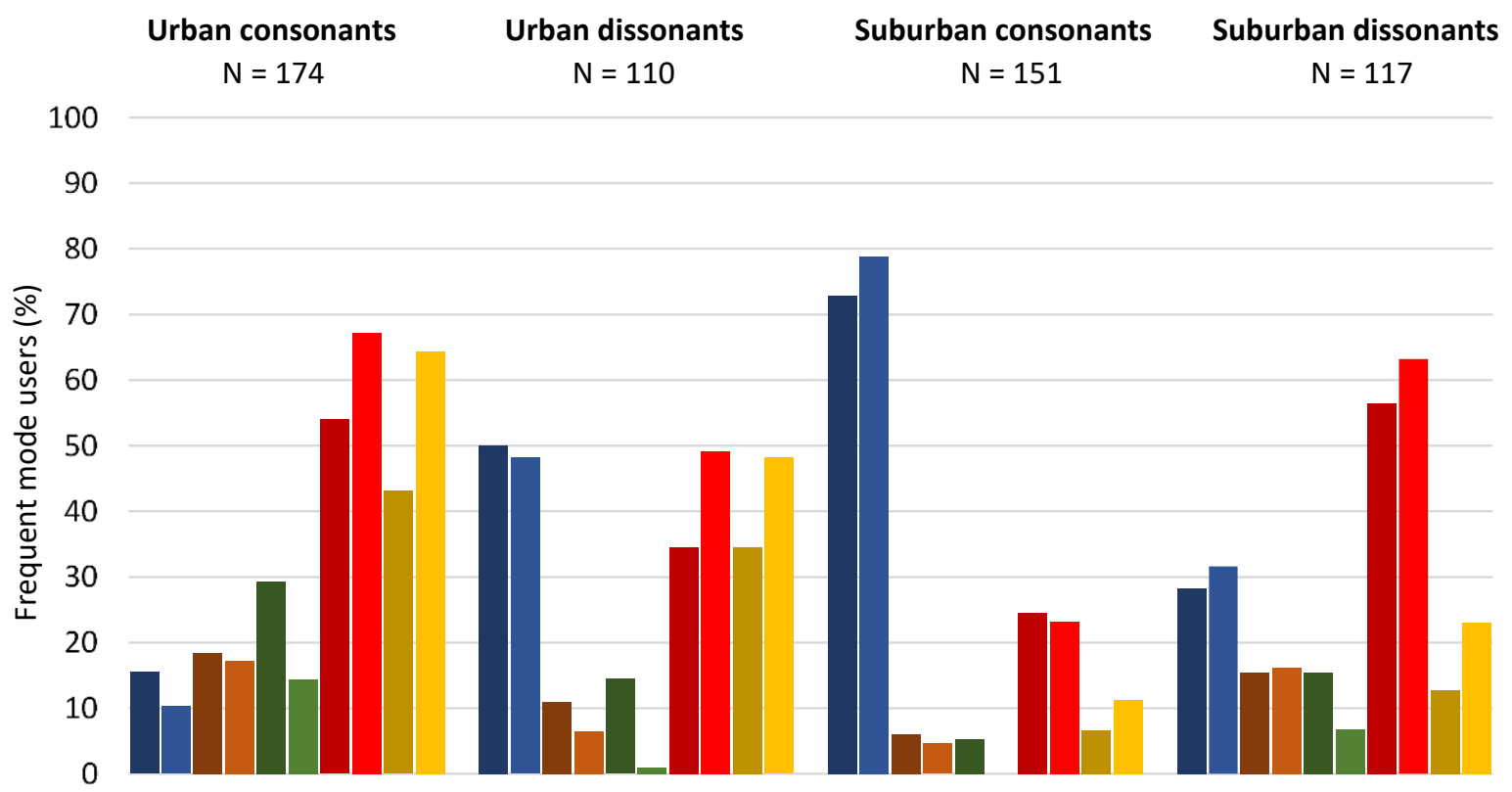

Figure 1. Percentage of frequent mode users of young (top) and older (bottom) adults according to their chosen neighborhood and travel attitudes 


\subsection{Determinants of the residential location choice, mode frequency, and attitudes}

Results from the previous sections give an indication of how the residential location choice and travel behavior are affected by respondents' age group, built environment and attitudes. However, in order to measure whether young adults' residential location choice, travel behavior and attitudes truly differ from older adults, regression analyses - controlling for socio-demographics ${ }^{5}$ - are needed. Table $6-$ showing the results of a binary logistic regression - indicates that young adults are more likely to choose an urban neighborhood to live in than older adults. Furthermore, choosing an urban residential neighborhood is also related with positive attitudes towards walking and negative attitudes towards car use and low-traffic investments. This might suggest that the 'pro low-traffic investments' factor represents more a dissatisfaction with suburban design (i.e., limited infrastructure for active travel, limited public transport, and car-oriented), than a liking for active travel and public transport. Finally, Table 6 indicates that relatively low-educated people (i.e., those without a university (college) degree) and couples with children mostly live in suburban-style neighborhoods.

Table 6. Binary logistic regression model for living in an urban residential neighborhood $(N=1,376)$

\begin{tabular}{|c|c|c|c|}
\hline & Coeff. & Sig. & OR \\
\hline Constant & -0.65 & $* *$ & 0.52 \\
\hline Young adult & 0.88 & $* * *$ & 0.41 \\
\hline Pro car & -0.90 & $* * *$ & 2.45 \\
\hline Pro low-traffic investments & -0.91 & $* * *$ & 0.40 \\
\hline Pro walking & 0.83 & $* * *$ & 2.28 \\
\hline Pro cycling & 0.08 & & 1.09 \\
\hline Gender (female) & -0.23 & $*$ & 0.79 \\
\hline Education (university (college) degree) & 0.98 & $* * *$ & 2.67 \\
\hline Income ( $\geq € 2500 /$ month net per household) & -0.09 & & 0.91 \\
\hline \multicolumn{4}{|l|}{ Household type } \\
\hline \multicolumn{4}{|l|}{ Couple with child(ren) (Ref.) } \\
\hline Single & 1.79 & $* * *$ & 5.96 \\
\hline Single parent & 1.01 & $* * *$ & 2.75 \\
\hline Couple without child(ren) & 1.31 & $* * *$ & 3.72 \\
\hline Other (e.g., living with parents, with friends) & 1.85 & $* * *$ & 6.34 \\
\hline-2 Log likelihood & \multicolumn{3}{|c|}{1321.25} \\
\hline Cox \& Snell R Square & \multicolumn{3}{|c|}{0.24} \\
\hline Nagelkerke R Square & \multicolumn{3}{|c|}{0.34} \\
\hline
\end{tabular}

Note: Coeff. = coefficient; Sig. = significance level; OR = odds ratio; ${ }^{*}=$ significant at $0.1>p>0.05,{ }^{* *}=$ significant at $0.05>p>0.01, * * *=$ significant at $p<0.01$.

\footnotetext{
${ }^{5}$ The following socio-demographics have been included in the regression analyses: $\operatorname{Gender}(0=\operatorname{man} ; 1=$ woman); Education ( 0 = low education (secondary school degree or less); 1 = high education (college or university degree)); Income ( 0 low income (net household income per month $<€ 2500) ; 1=$ high income (net household income per month $\geq € 2500$ ); Household type (Single; Single parent; Couple without child(ren); Couple with child(ren); Other (living with parents/friends). The household type variable has been included as a categorical variable in the binary logistic regressions with couple with child(ren) as reference category as we assumed that this category would have the most deviating location choice and mode frequency (which results partly confirmed). For the linear regressions, this variable has been included as a series of binary variables. Since all respondents are allocated into one of these categories - and the regression cannot be run with all the categories included - we decided to exclude the least valuable category, i.e., other (e.g., living with parents, with friends).
} 
Tables 7 and 8 show the results of binary logistic regressions for frequent mode use, for commute trips and leisure trips, respectively. In line with existing literature, mode choice is affected by both the residential environment and attitudes. People living in urban neighborhoods travel less by car and more by active travel and public transport, compared to suburban residents (although the differences are not significant for bus/tram use and cycling for commute trips). Positive attitudes towards car use positively affect car use and negatively affects the use of other modes. Positive attitudes towards walking have positive effects on walking and public transport use, and negative effects on car use (for leisure trips) and cycling. Positive attitudes towards cycling positively affect cycling, while negatively affecting the use of other modes. The pro low-traffic investments attitudes only have limited effects on respondents' mode frequency. Tables 7 and 8 also indicate that - when controlling for residential location, attitudes, and socio demographics - young adults do not travel significantly more (or less) with certain modes, compared to older adults. In terms of socio-demographics, highly-educated respondents commute more by train and cycle more often, while using bus/tram less frequently compared to lower-educated respondents. Women travel less by car and somewhat more by other modes than men, while income and the type of household only have limited effects on mode frequency.

Results from linear regressions - analyzing travel attitudes - show that young adults have a more positive attitude towards car use, while their attitudes towards walking and low-traffic investments is less positive compared to older adults (Table 9). Living in an urban neighborhood has a negative effect on attitudes towards car use and a positive effect on attitudes towards especially walking and cycling. Respondents living in a high-income household (i.e., a monthly net household income of at least $€ 2500$ ) have relatively negative attitudes towards active travel, while highly-educated respondents have a rather negative stance towards car use and a positive stance towards low-traffic investments and active travel. It should be noted, however, that the R-squares are rather low, indicating that the variances in attitudes are mainly explained by variables which were not included into the models. 
Table 7. Binary logistic regression model for frequent mode use for commute trips $(N=1,376)$

\begin{tabular}{|c|c|c|c|c|c|c|c|c|c|c|c|c|c|c|c|}
\hline & \multicolumn{3}{|c|}{$\begin{array}{l}\text { Frequent } \\
\text { car use }\end{array}$} & \multicolumn{3}{|c|}{$\begin{array}{c}\text { Frequent } \\
\text { bus/tram use }\end{array}$} & \multicolumn{3}{|c|}{$\begin{array}{l}\text { Frequent } \\
\text { train use }\end{array}$} & \multicolumn{3}{|c|}{$\begin{array}{l}\text { Frequent } \\
\text { cycling }\end{array}$} & \multicolumn{3}{|c|}{$\begin{array}{l}\text { Frequent } \\
\text { walking }\end{array}$} \\
\hline & Coeff. & Sig. & OR & Coeff. & Sig. & OR & Coeff. & Sig. & OR & Coeff. & Sig. & OR & Coeff. & Sig. & OR \\
\hline Constant & 0.27 & & 1.31 & -2.09 & $* * *$ & 0.12 & -2.85 & $* * *$ & 0.06 & -1.35 & $* * *$ & 0.26 & -2.05 & $* * *$ & 0.13 \\
\hline Residential location (urban) & -0.58 & $* * *$ & 0.56 & 0.21 & & 1.24 & 0.75 & $* * *$ & 2.12 & 0.25 & & 1.29 & 1.51 & $* * *$ & 4.53 \\
\hline Young adult & 0.03 & & 0.97 & -0.11 & & 1.12 & 0.23 & & 0.80 & 0.08 & & 0.93 & -0.16 & & 1.18 \\
\hline Pro car & 1.31 & $* * *$ & 0.27 & -0.70 & $* * *$ & 2.01 & -0.70 & $* * *$ & 2.01 & -0.44 & $* * *$ & 1.56 & -0.45 & $* * *$ & 1.57 \\
\hline Pro low-traffic investments & -0.06 & & 0.94 & -0.13 & & 0.88 & 0.20 & & 1.23 & -0.03 & & 0.97 & -0.28 & $* *$ & 0.76 \\
\hline Pro walking & -0.09 & & 0.91 & 0.94 & $* * *$ & 2.55 & 0.25 & $* *$ & 1.28 & -0.45 & $* * *$ & 0.64 & 0.94 & $* * *$ & 2.55 \\
\hline Pro cycling & -0.39 & $* * *$ & 0.68 & -0.89 & $* * *$ & 0.41 & -0.46 & $* * *$ & 0.63 & 1.87 & $* * *$ & 6.47 & -0.26 & $* *$ & 0.78 \\
\hline Gender (female) & -0.40 & $* * *$ & 0.67 & 0.28 & & 1.33 & -0.06 & & 0.94 & 0.37 & $* * *$ & 1.45 & 0.17 & & 1.18 \\
\hline Education (univ. (college)) & -0.05 & & 0.95 & -0.89 & $* * *$ & 0.41 & 0.81 & $* * *$ & 2.26 & 0.53 & $* * *$ & 1.69 & -0.33 & $*$ & 0.72 \\
\hline Income ( $\geq € 2500 /$ month) & 0.08 & & 1.09 & 0.01 & & 1.01 & 0.12 & & 1.12 & 0.05 & & 1.05 & -0.34 & $*$ & 0.71 \\
\hline \multicolumn{16}{|l|}{ Household type } \\
\hline \multicolumn{16}{|l|}{ Couple with child(ren) (Ref.) } \\
\hline Single & -0.56 & $* *$ & 0.57 & 0.23 & & 1.26 & 0.24 & & 1.27 & 0.38 & & 1.46 & 0.05 & & 1.05 \\
\hline Single parent & -0.10 & & 0.90 & 0.05 & & 1.05 & -0.43 & & 0.65 & 0.15 & & 1.16 & 0.12 & & 1.13 \\
\hline Couple without child(ren) & -0.38 & $*$ & 0.69 & -0.16 & & 0.86 & 0.13 & & 1.14 & 0.30 & & 1.35 & -0.12 & & 0.89 \\
\hline Other & 0.13 & & 1.14 & 0.03 & & 1.03 & 0.00 & & 1.00 & -0.05 & & 0.95 & -0.70 & $* *$ & 0.50 \\
\hline-2 Log likelihood & \multicolumn{3}{|c|}{1317.56} & \multicolumn{3}{|c|}{799.20} & \multicolumn{3}{|c|}{1189.42} & \multicolumn{3}{|c|}{1377.13} & \multicolumn{3}{|c|}{1272.56} \\
\hline Cox \& Snell R Square & \multicolumn{3}{|c|}{0.30} & \multicolumn{3}{|c|}{0.10} & \multicolumn{3}{|c|}{0.11} & \multicolumn{3}{|c|}{0.30} & \multicolumn{3}{|c|}{0.16} \\
\hline Nagelkerke R Square & \multicolumn{3}{|c|}{0.41} & \multicolumn{3}{|c|}{0.19} & \multicolumn{3}{|c|}{0.17} & \multicolumn{3}{|c|}{0.40} & \multicolumn{3}{|c|}{0.24} \\
\hline
\end{tabular}


Table 8. Binary logistic regression model for frequent mode use for leisure trips $(N=1,376)$

\begin{tabular}{|c|c|c|c|c|c|c|c|c|c|c|c|c|c|c|c|}
\hline & \multicolumn{3}{|c|}{$\begin{array}{c}\text { Frequent } \\
\text { car use }\end{array}$} & \multicolumn{3}{|c|}{$\begin{array}{c}\text { Frequent } \\
\text { bus/tram use }\end{array}$} & \multicolumn{3}{|c|}{$\begin{array}{l}\text { Frequent } \\
\text { train use }\end{array}$} & \multicolumn{3}{|c|}{$\begin{array}{l}\text { Frequent } \\
\text { cycling }\end{array}$} & \multicolumn{3}{|c|}{$\begin{array}{l}\text { Frequent } \\
\text { walking }\end{array}$} \\
\hline & Coeff. & Sig. & OR & Coeff. & Sig. & OR & Coeff. & Sig. & OR & Coeff. & Sig. & OR & Coeff. & Sig. & OR \\
\hline Constant & 0.34 & & 1.40 & -1.85 & $* * *$ & 0.16 & -3.51 & $* * *$ & 0.03 & -1.24 & $* * *$ & 0.29 & -1.67 & $* * *$ & 0.19 \\
\hline Residential location (urban) & -1.13 & $* * *$ & 0.32 & 0.02 & & 1.02 & 1.08 & $* * *$ & 2.95 & 0.89 & $* * *$ & 2.44 & 1.91 & $* * *$ & 6.74 \\
\hline Young adult & 0.33 & $*$ & 0.72 & 0.13 & & 0.88 & 0.58 & $* *$ & 0.56 & 0.10 & & 0.90 & -0.07 & & 1.08 \\
\hline Pro car & 1.82 & $* * *$ & 0.16 & -0.84 & $* * *$ & 2.33 & -1.16 & $* * *$ & 3.18 & -0.53 & $* * *$ & 1.69 & -0.55 & $* * *$ & 1.73 \\
\hline Pro low-traffic investments & 0.31 & $* *$ & 1.36 & -0.23 & & 0.80 & 0.30 & & 1.36 & -0.14 & & 0.87 & -0.64 & $* * *$ & 0.53 \\
\hline Pro walking & -0.51 & $* * *$ & 0.60 & 1.03 & $* * *$ & 2.80 & 0.28 & & 1.33 & -0.29 & $* *$ & 0.75 & 1.56 & $* * *$ & 4.74 \\
\hline Pro cycling & -0.47 & $* * *$ & 0.63 & -0.82 & $* * *$ & 0.44 & -0.36 & $* *$ & 0.70 & 2.13 & $* * *$ & 8.43 & -0.22 & $* *$ & 0.80 \\
\hline Gender (female) & -0.46 & $* * *$ & 0.63 & 0.49 & $* *$ & 1.63 & 0.27 & & 1.31 & 0.14 & & 1.15 & 0.01 & & 1.02 \\
\hline Education (univ. (college)) & 0.42 & $* *$ & 1.51 & -0.59 & $* *$ & 0.56 & -0.16 & & 0.86 & 0.59 & $* * *$ & 1.80 & -0.23 & & 0.80 \\
\hline Income ( $\geq € 2500 /$ month) & 0.29 & & 1.34 & -0.64 & $* *$ & 0.53 & -0.50 & $*$ & 0.61 & 0.17 & & 1.19 & -0.19 & & 0.83 \\
\hline \multicolumn{16}{|l|}{ Household type } \\
\hline \multicolumn{16}{|l|}{ Couple with child(ren) (Ref.) } \\
\hline Single & -0.59 & $* *$ & 0.56 & -0.22 & & 0.81 & 0.10 & & 1.11 & 0.24 & & 1.27 & -0.04 & & 0.96 \\
\hline Single parent & -0.07 & & 0.94 & 0.20 & & 1.23 & 0.08 & & 1.08 & 0.32 & & 1.38 & 0.26 & & 1.29 \\
\hline Couple without child(ren) & -0.25 & & 0.78 & -0.03 & & 0.97 & 0.30 & & 1.34 & 0.12 & & 1.13 & -0.06 & & 0.95 \\
\hline Other & -0.23 & & 0.80 & -0.45 & & 0.64 & 0.34 & & 1.40 & 0.25 & & 1.28 & -0.04 & & 0.96 \\
\hline-2 Log likelihood & \multicolumn{3}{|c|}{1144.95} & \multicolumn{3}{|c|}{773.65} & \multicolumn{3}{|c|}{659.29} & \multicolumn{3}{|c|}{1220.11} & \multicolumn{3}{|c|}{1358.27} \\
\hline Cox \& Snell R Square & \multicolumn{3}{|c|}{0.39} & \multicolumn{3}{|c|}{0.10} & \multicolumn{3}{|c|}{0.11} & \multicolumn{3}{|c|}{0.37} & \multicolumn{3}{|c|}{0.29} \\
\hline Nagelkerke R Square & \multicolumn{3}{|c|}{0.53} & \multicolumn{3}{|c|}{0.20} & \multicolumn{3}{|c|}{0.24} & \multicolumn{3}{|c|}{0.50} & \multicolumn{3}{|c|}{0.39} \\
\hline
\end{tabular}


Table 9. Linear regression model for travel attitudes $(\mathrm{N}=1,376)$

\begin{tabular}{|c|c|c|c|c|c|c|c|c|c|c|c|c|}
\hline & \multicolumn{3}{|c|}{ Pro car } & \multicolumn{3}{|c|}{$\begin{array}{l}\text { Pro low-traffic } \\
\text { investments }\end{array}$} & \multicolumn{3}{|c|}{ Pro walking } & \multicolumn{3}{|c|}{ Pro cycling } \\
\hline & Coeff. & $\begin{array}{c}\text { St. } \\
\text { coeff. }\end{array}$ & Sig. & Coeff. & $\begin{array}{c}\text { St. } \\
\text { coeff. }\end{array}$ & Sig. & Coeff. & $\begin{array}{l}\text { St. } \\
\text { coeff. }\end{array}$ & Sig. & Coeff. & $\begin{array}{c}\text { St. } \\
\text { coeff. }\end{array}$ & Sig. \\
\hline Constant & 0.49 & & $* * *$ & -0.32 & & $* * *$ & -0.38 & & $* * *$ & -0.45 & & $* * *$ \\
\hline Residential location (urban) & -0.45 & -0.23 & $* * *$ & 0.12 & 0.06 & $* *$ & 0.31 & 0.17 & $* * *$ & 0.16 & 0.09 & $* * *$ \\
\hline Young adult & 0.22 & 0.12 & $* * *$ & -0.20 & -0.11 & $* * *$ & -0.16 & -0.09 & $* * *$ & -0.01 & 0.00 & \\
\hline Gender (female) & 0.06 & 0.03 & & -0.04 & -0.02 & & 0.08 & 0.05 & $*$ & -0.03 & -0.02 & \\
\hline Education (univ. (college)) & -0.29 & -0.12 & $* * *$ & 0.39 & 0.17 & $* * *$ & 0.14 & 0.06 & $* *$ & 0.52 & 0.24 & $* * *$ \\
\hline Income ( $\geq € 2500 /$ month) & 0.07 & 0.04 & & -0.08 & -0.04 & & -0.16 & -0.09 & $* *$ & -0.11 & -0.07 & $* *$ \\
\hline \multicolumn{13}{|l|}{ Household type } \\
\hline Couple with child(ren) & 0.04 & 0.01 & & -0.05 & -0.02 & & 0.03 & 0.01 & & 0.10 & 0.04 & \\
\hline Single & 0.12 & 0.06 & & -0.19 & -0.10 & $* *$ & -0.02 & -0.01 & & -0.16 & -0.08 & $* *$ \\
\hline Single parent & 0.06 & 0.02 & & 0.13 & 0.04 & & 0.20 & 0.05 & & 0.13 & 0.04 & \\
\hline Couple without child(ren) & 0.07 & 0.04 & & -0.05 & -0.03 & & 0.07 & 0.04 & & 0.04 & 0.02 & \\
\hline R Square & & 0.08 & & & 0.05 & & & 0.05 & & & 0.08 & \\
\hline Adjusted R Square & & 0.07 & & & 0.04 & & & 0.04 & & & 0.07 & \\
\hline
\end{tabular}

Note: Coeff. = coefficient; St. coeff. $=$ standardized coefficient; Sig. $=$ significance level; $*=$ significant at $0.1>p>0.05, * *=\operatorname{significant}$ at $0.05>p>0.01, * * *=$ significant at $p$ $<0.01$. 


\section{Discussion and conclusion}

In this study we analyzed differences in the residential location choice, travel behavior and travel attitudes between young and older adults who recently relocated to selected urban and suburban neighborhoods in the city of Ghent (Belgium). The biggest share of young adults resides in urban areas, while older adults have an almost equal share living in urban and suburban neighborhoods. Despite urban residents in general travel less by car and more by public transport and active travel (see, for instance, Ewing \& Cervero, 2010), we only found limited differences in mode frequency between young and older adults (based on analyses of variance and binary logistic regressions). This might be partly explained by young adults having relatively positive attitudes towards car use and negative attitudes towards walking and low-traffic investments (although the latter attitudes have rather unclear effects on the residential location choice and mode frequency). These attitudes consequently seem to counterbalance young adults' effects of their residential environment on mode frequency. Or, in other words, young adults' residential location (i.e., mostly urban) might prevent them to travel more by car compared to older adults.

It is rather surprising that young adults - with a general liking for car use and disliking for walking choose to live in urban neighborhoods so frequently. This contradicts with the self-selection hypothesis, stating that people choose a residential location based on their travel preferences and needs (e.g., Cao et al., 2009). A dissonance between travel attitudes and the chosen neighborhood suggests that people either have a limited choice of where to live, or that the choice of where to live is based on reasons other than transport. A limited choice of where to live for young adults in our sample could be partly explained by young adults having lower household incomes and consequently a lower car possession (making it less obvious to live in a suburb) (Table 1). Living in urban neighborhoods might also be a strategy for young adults to save money since short distances to various activities and the presence of public transport services make it possible to live in urban areas without a car, avoiding costs such as car purchase, licensure, insurance, maintenance, fuel and parking. On the other hand, urban neighborhoods have a higher supply of small housing units (e.g., apartments) compared to suburban neighborhoods (which contain a lot of relatively large detached dwellings), making it easier for young adults without children to find an appropriate place of residence in urban areas. Furthermore, $47.0 \%$ of the young adults indicate that their residential relocation was a result of leaving the parental home (compared to $13.6 \%$ for older adults). As a result, their chosen neighborhood might be temporary and therefore needs to be less in line with travel/residential preferences. It might also be possible that young adults choose to live in urban areas not so much for the travel options it provides, but more for living an urban lifestyle and having access to multiple entertaining or relaxing leisure activities.

Results suggest that households - when having children - start relocating from urban areas to suburban areas. The age groups in our sample relocating most to suburban neighborhoods (i.e., more than $50 \%$ of respondents having the same age) are those between 35 and 46 years old. This seems in line with studies indicating that young adults might only be postponing suburban living and car use for some years, but in the end will have similar travel patterns as the previous generation (e.g., Delbosc, 2017; Jorritsma \& Berveling, 2014; Newbold \& Scott, 2017). In order to limit car use, policy makers and urban planners should therefore make urban areas more attractive to reside in and raise children, e.g., by creating more family-sized dwellings, green spaces and low-traffic areas. Since young adults 
seem to have rather positive attitudes towards car use, stimulating them to stay in urban neighborhoods might result in stable levels of car use; Car use which probably would increase when moving to suburbs. In other words, attractively-designed urban environments might actually counterbalance possible car liking.

This study partly contradicts with most other studies focusing on young adults' travel behavior, which mostly indicate that young adults have rather negative attitudes towards driving and a low frequency of car use. This indicates that further research analyzing the effects between the residential location choice, travel behavior and attitudes is necessary, and this in different geographical contexts - such as larger cities and regions with different mobility cultures - and using various methodological approaches. Although rather simple methodologies (e.g., regression analyses) have been used in this study - and therefore this study should be regarded as exploratory - valuable information has been found. However, more complex methodologies might be appropriate for future studies. Structural equation modelling, for instance, might analyze both direct and indirect effects (through the residential location choice) of travel attitudes on mode frequency for both young and older adults, controlling for self-selection effects. Furthermore, true longitudinal studies (e.g., mobility biographies (Müggenburg et al., 2015)) can provide insights into how and when people change their travel attitudes, residential preferences and travel behavior during their lives, taking into account certain life events (e.g., residential relocation, having children).

\section{Acknowledgments}

The authors would like to thank the two anonymous reviewers for their constructive comments and suggestions, making it possible to improve this paper. This work was supported by the Research Foundation - Flanders (FWO) under grant 12F2519N.

\section{References}

Alemi, F., Circella, G., Handy, S., Mokhtarian, P.L., 2018. What influences travelers to use Uber? Exploring the factors affecting the adoption of on-demand ride services in California. Travel Behaviour and Society 13, 88-104.

Blumenberg, E., Ralph, K., Smart, M., Taylor, B.D., 2016. Who knows about kids these days? Analyzing the determinants of youth and adult mobility in the US between 1990 and 2009. Transportation Research Part A 93, 39-54.

Blumenberg, E., Taylor, B.D., Smart, M., Ralph, K., Wander, M., 2012. What's youth got to do with it? Exploring the travel behavior of teens and young adults. University of California Transportation Center.

Busch-Geertsema, A., Lanzendorf, M., 2017. From university to work life - Jumping behind the wheel? Explaining mode change of students making the transition to professional life. Transportation Research Part A 106, 181-196.

Cao, J., Mokhtarian, P.L., Handy, S.L., 2009. Examining the impacts of residential self-selection on travel behaviour: a focus on empirical findings. Transport Reviews 29 (3), 359-395.

Chatterjee, K., Goodwin, P., Schwanen, T., Clark, B., Jain, J., Melia, S., Middleton, J., Plyushteva, A., Ricci, M., Santos, G., Stokes, G., 2018. Young People's Travel - What's Changed and Why? Review and Analysis. Report to Department for Transport. University of the West of England, Bristol. 
Cho, G.-H., Rodriguez, D.A., 2014. The influence of residential dissonance on physical activity and walking: evidence from the Montgomery County, MD, and Twin Cities, MN, areas. Journal of Transport Geography 41, 259-267.

Clark, B., Chatterjee, K., Melia, S., 2016a. Changes in level of household car ownership: the role of life events and spatial context. Transportation 43, 565-599.

Clark, B., Chatterjee, K., Melia, S., 2016b. Changes to commute mode: The role of life events, spatial context and environmental attitude. Transportation Research Part A 89, 89-105.

Delbosc, A., 2017. Delay or forgo? A closer look at youth driver licensing trends in the United States and Australia. Transportation 44 (5), 919-926.

Delbosc, A., Currie, G., 2013. Causes of Youth Licensing Decline: A Synthesis of Evidence. Transport Reviews 33 (3), 271-290.

Delbosc, A., Currie, G., 2014. Using discussion forums to explore attitudes toward cars and licensing among young Australians. Transport Policy 31, 27-34.

Delbosc, A., McDonald, N., Stokes, G., Lucas, K., Circella, G., Lee, Y., 2019. Millennials in cities: Comparing travel behaviour trends across six case study regions. Cities 90, 1-14.

Delbosc, A., Nakanishi, H., 2017. A life course perspective on the travel of Australian millennials. Transportation Research Part A 104, 319-336.

De Paepe, L., De Vos, J., Van Acker, V., Witlox, F., 2018. Changes in travel behavior during the transition from secondary to higher education: A case study from Ghent, Belgium. Journal of Transport and Land Use 11 (1), 477-498.

De Vos, J., Derudder, B., Van Acker, V., Witlox, F., 2012. Reducing car use: changing attitudes or relocating? The influence of residential dissonance on travel behavior. Journal of Transport Geography 22, 1-9.

De Vos, J., Ettema, D., Witlox, F., 2018. Changing travel behaviour and attitudes following a residential relocation. Journal of Transport Geography 73, 131-147.

De Vos, J., Ettema, D., Witlox, F., 2019. Effects of changing travel patterns on travel satisfaction: A focus on recently relocated residents. Travel Behaviour and Society 16, 42-49.

Ewing, R., Cervero, R., 2010. Travel and the built environment. A meta-analysis. Journal of the American Planning Association 76 (3), 265-294.

Frändberg, L., Vilhelmson, B., 2011. More or less travel: personal mobility trends in the Swedish population focusing on gender and cohort. Journal of Transport Geography 19, 1235-1244.

Garikapati, V.M., Pendyala, R.M., Morris, E.A., Mokhtarian, P.L., McDonald, N., 2016. Activity patterns, time use, and travel of millennials: a generation in transition? Transport Reviews 36 (5), 558-584.

Habib, K.N., 2018. Modelling the choice and timing of acquiring a driver's license: Revelations from a hazard model applied to the University students in Toronto. Transportation Research Part A 118, 374386.

Hopkins, D., 2016. Can environmental awareness explain declining preference for car-based mobility amongst generation $Y$ ? A qualitative examination of learn to drive behaviours. Transportation Research Part A 94, 149-163. 
Jorritsma, P., Berveling, B., 2014. Not car-less, but car-later. KiM Netherlands Institute for Transport Policy Analysis, The Hague, Netherlands.

Klein, N.J., Smart, M.J., 2017. Millennials and car ownership: Less money, fewer cars. Transport Policy $53,20-29$.

Kuhnimhof, T., Armoogum, J., Buehler, R., Dargay, J., Denstadli, J.M., Yamamoto, T., 2012a. Men Shape a Downward Trend in Car Use among Young Adults-Evidence from Six Industrialized Countries. Transport Reviews 32 (6), 761-779.

Kuhnimhof, T., Buehler, R., Wirtz, M., Kalinowska, D., 2012b. Travel trends among young adults in Germany: increasing multimodality and declining car use for men. Journal of Transport Geography 24, 443-450.

Lee, H., 2018. Are Millennials Coming to Town? Residential Location Choice of Young Adults. Urban Affairs Review. In Press. https://doi.org/10.1177/1078087418787668

Lee, Y., Circella, G., Mokhtarian, P.L., Guhathakurta, S., 2018. Are Millenials More Multimodal? A Latent-Class Analysis with Attitudes and Preferences. Paper presented at the $97^{\text {th }}$ Transportation Research Board Annual Meeting, Washington DC, January 7-11, 2018.

Lee, Y., Circella, G., Mokhtarian, P.L., Guhathakurta, S., 2019. Are All Millennials Really the Urban Hipster? A Latent Class Approach to Classify Today's Young Adults based on their Location Preference. Paper presented at the $98^{\text {th }}$ Tranportation Research Board Annual Meeting, Washington DC, January 13-17, 2019.

Line, T., Chatterjee, K., Lyons, G., 2010. The travel behaviour intentions of young people in the context of climate change. Journal of Transport Geography 18 (2), 238-246.

McDonald, N.C., 2015. Are millennials really the "go-nowhere" generation? Journal of the American Planning Association 81 (2), 90-103.

Melia, S., Chatterjee, K., Stokes, G., 2018. Is the urbanisation of young adults reducing their driving? Transportation Research Part A 118, 444-456.

Millard-Ball, A., Murray, G., Schure, J.T., Fox, C., Burkhardt, J., 2005. Car-sharing: where and how it succeeds. Transit Cooperative Research Program, report 108. Transportation Research Board, Washington DC.

Millsap, A., 2018. Location choice in early adulthood: Millennials versus Baby Boomers. Papers in Regional Science 97 (S1), S139-S167.

Moos, M., 2016. From gentrification to youthification? The increasing importance of young age in delineating high-density living. Urban Studies 53 (14), 2903-2920.

Müggenburg, H., Busch-Geertsema, A., Lanzendorf, M., 2015. Mobility biographies: A review of achievements and challenges of the mobility biographies approach and a framework for further research. Journal of Transport Geography 46, 151-163.

Newbold, K.B., Scott, D.M., 2017. Driving over the life course: The automobility of Canada's millennial, generation X, baby boomer and greatest generations. Travel Behaviour and Society 6, 57-63. 
Oakil, A.T.M., Manting, D., Nijland, H., 2016. Determinants of car ownership among young households in the Netherlands: The role of urbanisation and demographic and economic characteristics. Journal of Transport Geography 51, 229-235.

Prensky, M., 2009. H. sapiens digital: From digital immigrants and digital natives to digital wisdom. Innovate: Journal of Online Education 5 (3), Article 1.

Puhe, M., Schippl, J., 2014. User perceptions and attitudes on sustainable urban transport among young adults: Findings from Copenhagen, Budapest and Karlsruhe. Journal of Environmental Policy \& Planning 16 (3), 337-357.

Schwanen, T., Mokhtarian, P.L., 2005. What affects commute mode choice, neighbourhood physical structure or preferences toward neighborhoods? Journal of Transport Geography 13 (1), 83-99.

Thigpen, C., Handy, S., 2018. Driver's licensing delay: A retrospective case study of the impact of attitudes, parental and social influences, and intergenerational differences. Transportation Research Part A 111, 24-40.

Wang, K., Akar, G., Chen, Y.-J., 2018. Bike sharing differences among Millennials, Gen Xers, and Baby Boomers: Lessons learnt from New York City's bike share. Transportation Research Part A 116, 1-14. 